\title{
Pengaruh Struktur Modal, Capital Expenditure, Profitabilitas Dan Kebijakan Dividen Terhadap Nilai Perusahaan Pada Perusahaan BUMN Indonesia
}

\author{
Mispiyanti \\ Program Studi D3 Akuntansi, Sekolah Tinggi Ilmu Ekonomi Putra Bangsa, Indonesia \\ *Email korenpondensi: mispiyanti@gmail.com
}

Abstract

Some previous studies also show different results (research gap) about the factors that influence the value of the company. This study is to find out how the influence of capital structure, capital expenditure, profitability and dividend policy on corporate value in Indonesian BUMN companies partially and simultaneously. The population in this study is Indonesian BUMN companies that went public during 2015 - 2018 with selected samples based on purposive sampling criteria. The results of this study indicate that capital structure has no effect on the value of Indonesian BUMN companies in the 2015-2018 period, while capital expenditure and dividend policy have a positive effect on firm value and profitability has a negative effect on firm value. This indicates the existence of investment opportunities that attract new investors so they will get high returns.

Keywords: BUMN companies, capital structure, capital expenditure, company value, dividend policy, profitability.

Saran sitasi: Mispiyanti. (2020). Pengaruh Struktur Modal, Capital Expenditure, Profitabilitas Dan Kebijakan Dividen Terhadap Nilai Perusahaan Pada Perusahaan BUMN Indonesia. Jurnal Akuntansi dan Pajak, 20(2), 133-144. doi: http://dx.doi.org/10.29040/jap.v20i2.636

DOI: http://dx.doi.org/10.29040/jap.v20i2.636

\section{Pendahuluan}

Perkembangan BUMN sangat pesat pada tahun 2004, namun mengalami penurunan dikarenakan adanya merger, dan holding beberapa BUMN. Salah satu perusahaan BUMN yaitu PT Jasa Marga. Di Indonesia, PT Jasa Marga (Persero) merupakan perusahaan yang terkenal sebagai operator jalan tol. Ada securitisasi, project bound, dan global bound yang digunakan untuk memperkuat struktur permodalan karena investasi PT Jasa Marga yang luar biasa. PT Jasa Marga mengkaji Dana Investasi Infrastruktur Berbentuk Kontrak Investasi Kolektif (Dinfra), tetapi masih proses dengan pihak OJK dan Kementerian Keuangan. Hal ini untuk menjaga struktur permodalan, mengantisipasi deviasi, sehingga semua smooth. Finansial telah di backup oleh PT Jasa Marga tetapi kalau tidak diimprove maka struktur modalnya menjadi tidak sehat.

Kemudian ada Bank Rakyat Indonesia Tbk (BRI) yang melakukan roadshow penerbitan obligasi global ke Singapura, Hong Kong, dan London yang merupakan eksplorasi opsi pendanaan. Termasuk global bond sebagai diversifikasi pendaan dollar AS khususnya pendanaan jangka panjang. Jika BRI menerbitkan obligasi global, PT Bank Mayapada Internasional Tbk (MAYA) melakukan strategi rights issue untuk perkuat modal. Mayapada menerbitkan 910 juta saham baru melalui rights issue dengan target dana sebesar $\mathrm{Rp} 2$ triliun. Tujuannya untuk menambah kemampuan bank dalam meningkatkan kegiatan usaha, kinerja dan daya saing. Selain itu diharapkan dengan aksi korporasi ini bisa meningkatkan imbal hasil nilai investasi seluruh pemegang saham.

Ada pengaruh negatif struktur modal terhadap nilai perusahaan (Hasibuan et al., 2016). Hal ini dapat dijelaskan bahwa nilai perusahaan turun menyebabkan investor kurang percaya dan tidak berani mengambil risiko besar yang dapat merugikan. Hal ini di dukung oleh penelitian (Dewi and Wirajaya, 2013). Kesimpulan ini berbeda yaitu (Andrian, 2012)yang membuktikan bahwa struktur modal berpengaruh positif dan signifikan terhadap nilai perusahaan. 


\section{Jurnal Akuntansi dan Pajak, 20(02), 2019, 134}

Capital Expenditure merupakan pengeluaran uang untuk pembiayaan modal jangka panjang yang hasilnya baru akan diperoleh beberapa tahun kemudian.

Berdasarkan http://ekonomi.metrotvnews.com, tahun 2017, total capital expenditure perusahaan BUMN sebesar Rp475 triliun dinilai masih rendah.Penggunaan capital expenditure sebagai keputusan investasi dapat memberikan sinyal positif akan pertumbuhan perusahaan di masa yang akan datang, kemudian direspon baik oleh investor. Hal ini sesuai dengan signaling theory yaitu keputusan investasi dapat memberikan sinyal positif bagi para investor. Penelitian tentang capital expenditure pernah dilakukan oleh (Rahmiati and Sari, 2013) yang menemukan capital expenditure memiliki pengaruh yang signifikan dengan arah positif terhadap nilai perusahaan. Hal ini di dukung oleh (Andrian, 2012). Sebaliknya, (Sudiyatno et al., 2012), menyatakan bahwa rasio CAPEX tidak berpengaruh terhadap Tobin's Q.

Menurut penelitian (Indasari and Yadnyana, 2018), nilai perusahaan dapat dipengaruhi oleh besar kecilnya profitabilitas yang dihasilkan oleh perusahaan. Hasil penelitian tersebut mengemukakan bahwa semakin tinggi tingkat profitabilitas maka semakin tinggi nilai perusahaan sehingga semakin besar kemakmuran yang akan dibagikan kepada pemegang saham, oleh karena itu tingkat profitabilitas berpengaruh positif pada nilai perusahaan. (Hamidy et al., 2015) menemukan bahwa semakin tinggi profitabilitas maka perusahaan dapat menghasilkan keuntungan yang tinggi bagi pemegang saham, sehingga akan membuat para investor tertarik untuk menanamkan sahamnya pada perusahaan yang memberikan keuntungan besar. Artinya, perusahaan mempunyai prospek yang bagus mampu memicu investor untuk ikut meningkatkan permintaan saham. Permintaan saham yang meningkat akan menyebabkan nilai perusahaan juga ikut meningkat. Hal ini didukung oleh (Gunawan, 2016) yang menemukan bahwa Net Profit Margin berpengaruh positif terhadap rasio Tobin's Q.

Kebijakan dividen dari BUMN merupakan isu yang paling penting bagi penerimaan negara maupun bagi perkembangan dari BUMN tersebut. Pertimbangan dalam kebijakan dividen BUMN yaitu apakah laba BUMN lebih digunakan untuk membiayai investasi atau diberikan sebagai dividen yang kemudian digunakan untuk membiayai belanja pemerintah. Perdebatan lainnya yaitu penarikan dividen BUMN untuk membiayai APBN akan memberikan dampak kemampuan keuangan BUMN dalam melakukan pengembangan usaha.Jika perusahaan memutuskan untuk tidak ada peningkatan dalam pembagian dividen maka harga saham bisa menurun dan nilai perusahaan bisa menurun dan begitu juga sebaliknya. Oleh karena itu kebijakan dividen dapat mempengaruhi nilai perusahaan jika dilihat dari keputusan perusahaan dalam melakukan kebijakan dividen. Penelitian kebijakan dividen terhadap nilai perusahaan telah dilakukan oleh (Senata, 2016) yang menyatakan kebijakan dividen berpengaruh terhadap nilai perusahaan. Sedangkan (Anita and Yulianto, 2016) menyatakan berbeda yaitu kebijakan dividen tidak berpengaruh terhadap nilai perusahaan.

Nilai perusahaan dapat memberikan kemakmuran pemegang saham secara maksimum apabila harga saham meningkat. Semakin tinggi harga saham maka semakin tinggi pula kemakmuran pemegang saham. Harga pasar saham merupakan cerminan dari keputusan investasi, pendanaan dan pengelolaan aset yang merupakan presentasi dari kekayaan pemegang saham dan perusahaan.Martono dalam (Sarafina and Saifi, 2017) menyatakan bahwa nilai perusahaan dapat dilihat dari nilai saham perusahaan yang bersangkutan. Pengukuran nilai perusahaan yang digunakan salah satunya adalah menggunakan rasio Tobins'Q. Tobins'Q pernah dipakai oleh (Sarafina and Saifi, 2017), sebagai salah satu ukuran nilai perusahaan. Berdasarkan hal tersebut maka perlu diketahuibagaimana pengaruh struktur modal,capital expenditure, profitabilitas dan kebijakan dividen terhadap nilai perusahaan BUMN yang terdaftar di BEI secara parsial dan simultanuntuk periode 2015 - 2018 .

\section{Signalling Theory}

Teori sinyal (signaling theory) dibangun sebagai upaya untuk memaksimalkan nilai perusahaan. Adanya asimetri informasi antara manajemen perusahaan dan pihak-pihak yang berkepentingan dengan informasi tersebut ditunjukkan dalam teori sinyal. Asumsi utama dari teori sinyal ini memberikan ruang bagi investor untuk mengetahui bagaimana keputusan yang akan diambilnya berkaitan dengan nilai perusahaan tersebut. Teori sinyal mengemukakan tentang bagaimana seharusnya perusahaan memberikan sinyal berupa informasi mengenai apa yang sudah 


\section{Jurnal Akuntansi dan Pajak, 20(02), 2019, 135}

dilakukan oleh manajemen untuk merealisasikan keinginan pemilik (investor).

\section{Nilai perusahaan}

Nilai perusahaan didefinisikan sebagai nilai pasar. Nilai pasar perusahaan terjadi karena adanya harga pasar dari saham yang terbentuk antara pembeli dan penjual ketika terjadi transaksi. Nilai pasar perusahaan yang dibentuk melalui indikator nilai pasar saham merupakan cerminan dari nilai aset perusahaan sesungguhnya. Nilai pasar saham ini sangat dipengaruhi oleh peluang-peluang investasi. Adanya peluang investasi memberikan sinyal positif tentang pertumbuhan perusahaan dimasa yang akan datang, sehingga meningkatkan nilai perusahaan (Kurnia, 2017). Rasio Tobin's Q merupakan rasio yang memberikan informasi paling baik karena dalam Tobin's Q memasukkan semua unsur yaitu hutang, modal, serta seluruh aset perusahaan. Nilai Tobin's Q menggambarkan suatu kondisi peluang investasi yang dimiliki perusahaan (Kurnia, 2017). Jika nilai Tobin's Q menunjukkan diatas satu akan dapat menimbulkan atau meningkatkan minat para investor baru yang menunjukkan bahwa investasi dalam aktiva menghasilkan laba yang lebih tinggi. Bila nilai Tobin's Q dibawah satu maka investasi kepada perusahaan tersebut kurang menarik.

\section{Teori trade-off}

Dalam (Harjito, 2011), Teori trade-off menyatakan bahwa hubungan antara struktur modal dengan nilai perusahaan terdapat suatu tingkat leverage yang optimal. Menurut teori ini agar tercapai struktur modal yang optimal perusahaan perlu menyeimbangkan agency cost of financial distress dan the tax advantage of debt financing. Menurut teori ini struktur modal yang optimal dicapai, apabila nilai sekarang dari tax shield hutang adalah sama dengan nilai sekarang dari biaya kesulitan keuangan hutang. Secara umum teori ini menegaskan bahwa apabila perusahaan ingin meningkatkan nilai perusahaan melalui indikator earning per share (EPS), maka pembiayaan investasi tambahan hurus dibiayai oleh hutang. Hal ini terjadi karena pembiayaan dengan hutang, perusahaan dapat memperoleh penghematan pajak sekaligus mempertahankan jumlah saham beredar. Keadaan ini mendorong pendapatan per lembar saham (EPS) akan lebih tinggi. Sebaliknya apabila perusahaan mengalami kegagalan dalam mengelola investasi yang berakibat pada ketidakmampuan membayar bunga dan pokok pinjaman, maka posisi perusahaan berada diambang kebangkrutan. Apabila semua biaya akibat kesulitan keuangan tersebut sama dengan jumlah tambahan pendapatan dari penghematan pajak (taxe shield of debt), maka struktur modal perusahaan dianggap sudah optimal. Teori trade-off menyatakan bahwa terdapat rasio hutang yang optimal atau struktur modal yang optimal di dalam keuangan perusahaan. Namun sebaliknya, perusahaan membuat keputusan struktur modal berdasarkan sumber modal yang paling mahal biaya modalnya. Itu adalah sumber modal yang kurang sensitif terhadap masalah asimetri informasi yang mengikuti urutan srukturnya, yaitu mulai dari laba ditahan; diikuti oleh hutang dan terakhir ekuitas.

\section{Struktur Modal}

Irawati dalam (Lestari, 2015)menyatakan struktur modal merupakan susunan dari jenis-jenis modal yang diperoleh perusahaan beserta jumlah nilai-nilainya dalam bentuk hutang jangka panjang dan modal sendiri. Risiko yang semakin tinggi cenderung menurunkan harga saham, tetapi meningkatkan tingkat pengembalian yang diharapkan (expected rate of return). Keseimbangan antara risiko dan pengembalian yang maksimum harga saham disebut struktur modal yang optimal. Struktur modal yang optimal merupakan struktur yang akan memaksimalkan harga saham perusahaan, dan struktur ini pada umumnya yaitu rasio hutang yang lebih rendah daripada rasio yang memaksimalkan earning per share yang diharapkan.

\section{Capital Expenditure}

CAPEX adalah segala bentuk pengeluaran yang dialokasikan pada penambahan, perbaikan atau peningkatan kualitas aktiva yang menghasilkan manfaat jangka panjang (Mutiara and Kartawinata, 2015). Capital expenditure atau pembelanjaan modal merupakan salah satu konsep penting dalam teori keuangan suatu perusahaan. Beberapa fungsi keuangan utama yang dilakukan manajer keuangan adalah pembuatan keputusan yang berkaitan dengan aktifitas pencarian dana (financing decision) serta pembuatan keputusan yang berkaitan dengan bagaimana dana yang diperoleh tersebut diinvestasikan (investment decision).

\section{Profitabilitas}

Bagi perusahaan pada umumnya masalah profitabilitas adalah lebih penting dari persoalan laba, karena laba yang besar saja belumlah merupakan ukuran bahwa perusahaan itu telah dapat bekerja dengan efisien. Efisiensi baru dapat diketahui dengan membandingkan laba tersebut, 


\section{atau dengan kata lain menghitung tingkat profitabilitasnya. Dengan demikian maka yang harus diperhatikan oleh perusahaan adalah tidak hanya bagaimana usaha untuk memperbesar laba, tetapi yang lebih penting adalah usaha untuk meningkatkan profitabilitasnya. Berhubungan dengan itu maka bagi perusahaan pada umumnya usahanya lebih diarahkan untuk mendapatkan titik profitabilitas maksimal dari pada laba maksimal. Oleh karena itu semakin tinggi profitabilitas perusahaan maka mencerminkan bahwa semakin tinggi tingkat efisiensi perusahaan.}

\section{Theory Bird in The Hand}

Teori ini merupakan teori yang dikemukakan oleh Myron Gordon dan John Lintner. Berdasarkan bird in the hand theory yang dijelaskan dalam (Esana and Darmawan, 2017), pembagian dividen merupakan suatu pertanda bagi investor, dimana kenaikan dividen yang sangat besar menandakan bahwa manajemen merasa optimis atas masa depan perusahaan. Dividen yang meningkat mencerminkan para investor berorientasi pada dividen. Hal tersebut akan menyebabkan meningkatnya harga saham atau dengan kata lain besarnya dividen dapat mempengaruhi harga saham perusahaan yang akan berdampak pada nilai perusahaan.

\section{Kebijakan dividen}

Kebijakan dividen adalah suatu keputusan untuk menentukan berapa besar bagian dari pendapatan perusahaan akan dibagikan kepada para pemegang saham dan akan diinvestasikan kembali atau ditahan di dalam perusahaan (Zurohtun and Yulianti, 2013). Kebijakan dividen perusahaan tercermin dalam rasio pembayaran dividen (Dividend Payout Ratio). Dividend Payout Ratio adalah perbandingan antara dividen yang dibayarkan dengan laba bersih yang didapatkan dan biasanya disajikan dalam bentuk prosentase. Dividen merupakan pembagian keuntungan perusahaan kepada para pemegang saham yang sebanding dengan jumlah lembar saham yang dimilikinya. Dalam pembayaran dividen, perusahaan dapat menggunakan bentuk-bentuk tertentu, seperti dividen tunai, dividen dalam bentuk aktiva yang lain, dividen dalam bentuk surat utang ataupun dividen dalam bentuk saham (Zurohtun and Yulianti, 2013). Pembagian dividen umumnya didasarkan pada akumulasi laba yaitu laba ditahan atau pos modal lainnya seperti tambahan modal disetor. Sedangkan dividend payout (pembayaran dividen) ak, 20(02), 2019, 136

merupakan salah satu cara untuk mengembalikan keuntungan perusahaan kepada pemegang saham.

\section{Hipotesis Penelitian}

\section{$\mathrm{H}_{1}$ : Struktur modal berpengaruh negatif terhadap nilai perusahaan BUMN yang terdaftar di BEI}

Bagi perusahaan sangat penting untuk memperkuat kestabilan keuangan yang dimilikinya, karena perubahan dalam struktur modal diduga bisa menyebabkan perubahan nilai perusahaan.Turunnya nilai perusahaan bisa mempengaruhi pada turunnya nilai saham perusahaan tersebut. (Situmeang and Wiagustini, 2018) dalam hasil penelitiannya menyatakan bahwa struktur modal berpengaruh signifikan dengan arah negatif terhadap nilai perusahaan. Penambahan utang perusahaan dapat menurunkan kemampuan perusahaan dalam mengelola asetnya, hal ini dikarenakan utang perusahaan BUMN listed tahun 2012-2016 terlalu tinggi atau telah melewati batas struktur modal optimal sehingga sesuai dengan teori trade off, struktur modal yang melewati batas optimal sejauh manfaat yang dibutuhkan justru dapat menurunkan nilai perusahaan. (Supit et al., 2015) dan (Hasibuan et al., 2016) juga menemukan hasil penelitian yang sama.

\section{$\mathrm{H}_{2}$ : Capital expenditure berpengaruh positif terhadap nilai perusahaan BUMN yang terdaftar di BEI}

Capital Expenditure perusahaan dapat memperkecil risiko ketidaklancaran proses produksi. Apabila terjadi kerusakan pada aktiva tetap, maka dengan secepatnya dapat diperbaiki, dimodernisasi atau membeli aktiva baru. Sehingga proses produksi berjalan lancar dan permintaan konsumen dapat terpenuhi maka akan kinerja perusahaan semakin membaik. Kinerja perusahaan yang baik akan meningkatkan harga saham perusahaan dan selanjutnya mempengaruhi peningkatan nilai perusahaan. (Andrian, 2012) dalam penelitiannya menunjukkan bahwa capital expenditure berpengaruh positif terhadap nilai perusahaan. (Rahmiati and Sari, 2013) juga menemukan hasil penelitian yang sama.

\section{$\mathrm{H}_{3}$ : Profitabilitas berpengaruh positif terhadap nilai perusahaan BUMN yang terdaftar di BEI}

Profitabilitas adalah hasil akhir dari sejumlah dan keputusan manajemen perusahaan atau kemampuan perusahaan menghasilkan laba dari kegiatan yang dilakukan dalam periode akuntansi. 
Dalam penelitian ini, profitabilitas diwakilkan dengan Net Profit Margin (NPM). Rasio Net Profit Margin yaitu rasio pendapatan terhadap penjualan. Semakin tinggi rasio tersebut maka kemampuan memperoleh laba oleh perusahaan akan semakin besar. (Wahyu and Mahfud, 2018)menemukan bahwa Net Profit Margin berpengaruh positif terhadap nilai perusahaan. NPM yang besar pada suatu perusahaan dapat digunakan oleh investor dalam pengambilan keputusan untuk melakukan pembelian saham emiten, karena laba bersih meningkat mampu mempengaruhi minat investor untuk menginvestasikan dananya pada suatu perusahaan, yang akhirnya akan menyebabkan harga saham perusahaan meningkat. Harga saham yang meningkat akan diikuti pula dengan peningkatan nilai perusahaan. Hal ini didukung oleh (Gunawan, 2016) yang menemukan bahwa Net Profit Margin berpengaruh positif terhadap rasio Tobin's Q.

$\mathrm{H}_{4}$ : Kebijakan dividen berpengaruh positif terhadap nilai perusahaan BUMN yang terdaftar di BEI

BUMN mempunyai kebijakan yang berbeda terkait dengan kebijakan pembayaran dividen. Hal ini dikarenakan BUMN dituntut untuk memberikan dividen sebanyak-banyaknya, karena dividen BUMN akan masuk dalam APBN. Selain itu BUMN yang go publik akan lebih disorot kinerjanya, karena diharapkan dengan program privatisasi kinerja BUMN akan meningkat.(Senata, 2016)yang menyatakan kebijakan dividen berpengaruh terhadap nilai perusahaan.(Rialdy, 2018)menyatakan bahwa kebijakan dividen berpengaruh positif dan signifikan terhadap nilai perusahaan dimana besar kecilnya dividen yang dibayarkan akan sangat mempengaruhi pencapaian tujuan memaksimumkan kesejahteraan bagi pemegang saham. Hal ini juga didukung oleh (Rasyid and Yuliandhari, 2018) yang menemukan bahwa kebijakan dividen berpengaruh terhadap nilai perusahaan BUMN.

$\mathrm{H}_{5}$ : Struktur modal, capital expenditure, dan profitabilitas secara bersama-sama berpengaruh terhadap nilai perusahaan BUMN yang terdaftar di BEI

\section{Metode Penelitian}

\section{Model Penelitian}

Dari 4 (empat) hipotesis yang telah dirumuskan, maka dapat dibuat sebuah model penelitian sebagai berikut:

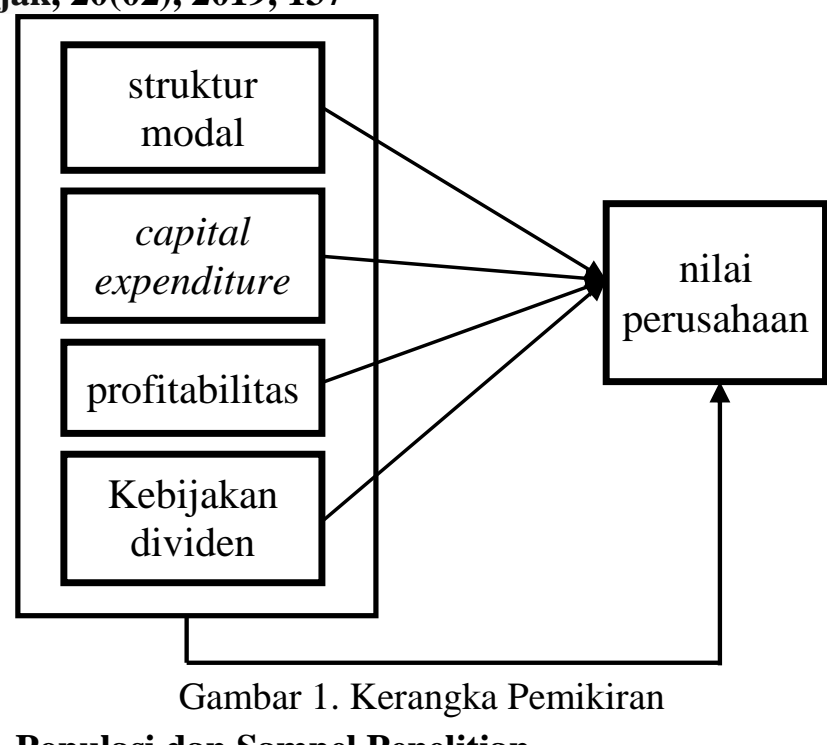

\section{Populasi dan Sampel Penelitian}

Populasi dalam penelitian ini adalah semua perusahaan BUMN yang terdaftar di Bursa Efek Indonesia (BEI) selama tahun 2015 - 2018. Berdasarkan populasi tersebut, sampel penelitian ini berdasarkan purposive sampling. Adapun kriteria purposive sampling dalam penelitian ini yaitu:

1. Perusahaan BUMN yang terdaftar di BEI selama tahun $2015-2018$

2. Perusahaan BUMN yang memperoleh laba selama periode penelitian

\section{Jenis Data}

Penelitian ini termasuk jenis kuantitatif menggunakan data sekunder tentang struktur modal, capital expenditure, profitabilitas, kebijakan dividen dan nilai perusahaan pada perusahaan BUMN Indonesia.

\section{Metode Pengumpulan Data}

Metode pengumpulan data yang akan digunakan pada penelitian ini adalah metode dokumentasi data sekunder yaitu laporan keuangan perusahaan BUMN yang terdaftar di Bursa Efek Indonesia (BEI).

\section{Definisi Operasional Variabel}

Berdasarkan judul penelitian di atas, maka variabel-variabel yang terkait dalam penelitian ini adalah:

1. Variabel Bebas (X)

Variabel bebas sering juga disebut dengan variabel independen yang akan mempengaruhi variabel terikat. Adapun variabel bebas dalam penelitian ini adalah:

\section{a. Struktur Modal}

Dalam penelitian ini, struktur modal diwakili oleh DER yang merupakan rasio yang digunakan untuk mengukur keberhasilan kinerja manajer dalam menentukan keputusan struktur modal dan dalam 


\section{Jurnal Akuntansi dan Pajak, 20(02), 2019, 138}

mengelola perusahaan. DER dalam penelitian ini mengacu pada Andrian (2012).

DER $=\frac{\text { Total liabilitas }}{\text { Total equity }} \times 100 \%$

\section{b. Capital Expenditure}

Capital expenditure adalah segala bentuk pengeluaran yang dialokasikan pada penambahan, perbaikan atau peningkatan kualitas aktiva yang menghasilkan manfaat jangka panjang. Pada penelitian ini capital expenditure dihitung dengan menggunakan rasio CAPEX yang didapat dari prosentase perbandingan nilai total fixed asset tahun ini dengan total fixed asset pada tahun sebelumnya yang tercantum pada laporan tahunan perusahaan seperti yang dijelaskan oleh (Sofiamira and Asandimitra, 2017) dengan rumus sebagai berikut:

CAPEX $X_{t}=\Delta F A_{t}$

c. Profitabilitas

Profitabilitas adalah kemampuan perusahaan dalam menghasilkan laba. Dalam penelitian ini profitabilitas diproksikan Net Profit Margin (NPM). Rasio NPM menurut (Gunawan, 2016) adalah rasio yang mengukur tingkat keuntungan yang dapat dicapai oleh perusahaan dihubungkan dengan penjualannya. Rumus NPM adalah sebagai berikut:

$N P M=\frac{\text { Earning After Interest and Tax }}{\text { Sales }}$

d. Kebijakan Dividen

Variabel kebijakan dividen diproksikan dengan Dividend Payout Ratio (DPR), yang merupakan perbandingan antara jumlah dividen yang dibayarkan per lembar saham dan jumlah laba yang dibayarkan per lembar saham. Dividend Payout Ratio ini mengacu pada (Supit et al., 2015).

$D P R=\frac{\text { Dividen per lembar saham }}{\text { Laba per lembar saham }}$

2. Variabel Tidak Bebas

Variabel tidak bebas sering juga disebut dengan variabel dependen yang akan mempengaruhi variabel tidak terikat. Adapun variabel dependen dalam penelitian ini yaitu nilai perusahaan. Perhitungan untuk menentukan nilai perusahaan yaitu Tobin's Q. Tobin's Q ditemukan di dalam penggunaannya, menurut (Sudiyatno and Puspitasari, 2010)

Formulasi rumusnya sebagai berikut:

$Q=\frac{M V S+D}{T A}$

dimana:

MVS : Market Value Share

D : Debt

TA : Firm's asset's
(MVS) merupakan nilai pasar saham yang diperoleh dari perkalian jumlah saham yang beredar dengan harga saham (Outstanding Shares* Stock Price). Debt merupakan besarnya nilai pasar hutang, dimana nilai ini dapat dihitung dengan menggunakan persamaan sebagai berikut:

$D=(A V C L-A V C A)+A V L T$ dimana:

AVCL : Accounting value of the firm's Current Liabilities. $=$ Short Term Debt + Taxes Payable.

AVLTD : Accounting value of the firm's Long Term Debt. $=$ Long Term Debt .

AVCA : Accounting value of the firm's CurrentAssets. $=$ Cash + Account Receivable + Inventories.

\section{Metode Analisis Data}

Teknik analisis regresi berganda

Teknik analisis data menggunakan uji asumsi klasik terdiri dari uji multikolinieritas, uji heteroskedastisitas, uji normalitas, uji autokorelasi dan uji hipotesis terdiri atas uji koefisien determinasi, uji beda independent sample t-test, uji pengaruh simultan ( $F$ test ) dan uji signifikansi parameter individual ( $\mathrm{t}$ test). Maka, model analisis dalam penelitian ini dapat dijabarkan sebagai berikut:

$Y=a+\beta_{1} X_{1}+\beta_{2} X_{2}+\beta_{3} X_{3}+\beta_{4} X_{4}+e$

Dimana:

Y : Nilai Perusahaan

a : konstanta

$\beta_{1,2,3,4}$ : koefisien regresi untuk variabel $X_{1}, X_{2}, X_{3}$

$\mathrm{X}_{1} \quad$ : Struktur Modal

$\mathrm{X}_{2} \quad$ : Capital Expenditure

$\mathrm{X}_{3} \quad$ : Profitabilitas

$\mathrm{X}_{4} \quad$ : Kebijakan Dividen

e : Faktor pengganggu di luar model (kesalahan regresi)

\section{Hasil dan Pembahasan}

\subsection{Hasil penelitian}

Metode analisis yang digunakan dalam penelitian ini adalah analisis regresi linier berganda. Analisis regresi ini bertujuan untuk peroleh gambaran yang menyeluruh mengenai hubungan antara variabel independen dan variabel dependen secara parsial maupun secara simultan.

\section{Uji asumsi klasik}

Sebelum dilakukan pengujian analisis regresi linier berganda terhadap hipotesis penelitian, maka terlebih dahulu perlu dilakukan suatu pengujian asumsi klasik atas data yang akan diolah sebagai berikut: 


\section{Uji normalitas}

Uji normalitas bertujuan untuk menguji apakah dalam model regresi, variabel pengganggu atau residual memiliki distribusi normal. Seperti diketahui bahwa uji $\mathrm{t}$ dan $\mathrm{F}$ mengasumsikan bahwa

\section{Jurnal Akuntansi dan Pajak, 20(02), 2019, 139}

nilai residual mengikuti distribusi normal. Untuk menguji apakah data berdistribusi normal atau tidak dilakukan uji statistik Kolmogorov-Smirnov Test. Residual berdistribusinormal jika memiliki nilai signifikansi >0,05 (Ghozali, 2018).

Tabel 1.

One-Sample Kolmogorov-Smirnov Test

\begin{tabular}{|c|c|c|c|c|c|c|c|}
\hline & & & $\begin{array}{c}\text { SQRT_ }_{-} \\
\mathrm{X}_{1} \\
\end{array}$ & SQRT_X ${ }_{2}$ & $\begin{array}{c}\text { SQRT }_{-} \\
\mathrm{X}_{3} \\
\end{array}$ & $\begin{array}{c}\text { SQRT_ }_{-} \\
\mathrm{X}_{4} \\
\end{array}$ & $\begin{array}{c}\text { SQRT_ }_{-} \\
\mathrm{Y}\end{array}$ \\
\hline $\mathrm{N}$ & & & 76 & 68 & 69 & 76 & 72 \\
\hline Normal & Mean & & 1,4924 & 1048166,7598 & ,3296 & ,4289 & ,9859 \\
\hline Parameters ${ }^{\mathrm{a}, \mathrm{b}}$ & Std. Deviation & & ,70954 & 1009940,80054 &, 14462 & ,23644 & , 14504 \\
\hline Most Extreme & Absolute & & ,099 &, 156 & ,090 &, 130 &, 120 \\
\hline Differences & Positive & & ,099 &, 156 & ,090 & ,123 & 120 \\
\hline & Negative & &,- 098 &,- 151 &,- 088 &,- 130 &,- 077 \\
\hline Test Statistic & & & ,099 &, 156 & ,090 & ,130 &, 120 \\
\hline Asymp. Sig. (2-ta & led) & &, $064^{d}$ &, $000^{\circ}$ & $200^{\mathrm{c}, \mathrm{e}}$ &, $003^{c}$ &, $012^{\mathrm{c}}$ \\
\hline Monte Carlo Sig. & Sig. & &, $423^{d}$ & $063^{\mathrm{d}}$ &, $606^{d}$ &, $141^{d}$ & $232^{\mathrm{d}}$ \\
\hline (2-tailed) & 99\% Confidence & Lower Bound & ,410 &, 057 &, 594 & ,132 &, 221 \\
\hline & Interval & Upper Bound & ,436 & ,069 & 619 & , 150 & ,243 \\
\hline
\end{tabular}

a. Test distribution is Normal.

b. Calculated from data.

c. Lilliefors Significance Correction.

d. Based on 10000 sampled tables with starting seed 79654295 .

e. This is a lower bound of the true significance.

Dalam penelitian ini, awalnya semua variabel tidak normal $(<0,05)$. Oleh karena itu perlu dilakukan proses transformasi data berdasarkan grafik histogram yang terbentuk. Setelah dilakukan tarnsformasi data, berdasarkan tabel 1. nilai signifikansi $>0,05$ untuk masing-masing variabel sehingga dapat disimpulkan bahwa data yang diuji berdistribusi normal.

\section{Uji Multikolinieritas}

Menurut (Ghozali, 2018) uji multikolinieritas bertujuan untuk menguji apakah model regresi ditemukan adanya korelasi antar variabel bebas (independen). Untuk menguji multikolinieritas dengan caramelihat nilai VIF masing-masing variabel independen, jika nilai VIF $<10$, maka dapat disimpulkan data bebas dari gejala multikolinieritas.

Tabel 2.

Coefficients $^{\mathbf{a}}$

\begin{tabular}{|c|c|c|c|c|c|c|c|c|}
\hline \multirow{2}{*}{\multicolumn{2}{|c|}{ Model }} & \multicolumn{2}{|c|}{$\begin{array}{l}\text { Unstandardized } \\
\text { Coefficients }\end{array}$} & \multirow{2}{*}{\begin{tabular}{c|}
$\begin{array}{c}\text { Standardized } \\
\text { Coefficients }\end{array}$ \\
Beta
\end{tabular}} & \multirow[b]{2}{*}{$\mathrm{t}$} & \multirow[b]{2}{*}{ Sig. } & \multicolumn{2}{|c|}{ Collinearity Statistics } \\
\hline & & $\begin{array}{ll}\mathrm{B} \\
\end{array}$ & Std. Error & & & & Tolerance & VIF \\
\hline 1 & (Constant) & 910 &, 055 & & 16,684 &, 000 & & \\
\hline & SQRT_X1 &, 001 &, 025 & ,004 & ,028 & ,977 & ,796 & 1,257 \\
\hline & SQRT_X2 & $4,839 \mathrm{E}-8$ & ,000 & ,336 & 2,565 & ,013 & ,770 & 1,298 \\
\hline & SQRT_X3 &,- 344 & , 159 &,- 356 & $-2,161$ & 035 & ,487 & 2,053 \\
\hline & SQRT_X4 & ,320 &, 105 & 461 & 3,061 & ,003 & ,581 & 1,720 \\
\hline
\end{tabular}

a. Dependent Variable: SQRT_Y

Berdasarkan tabel 2, hasil perhitungan nilai Tolerance menunjukkan tidak adanya variabel independen yang memiliki nilai Tolerance kurang dari 0,10 yang berarti tidak ada korelasi antar variabel independen yang nilainya lebih dari $95 \%$.
Hasil perhitungan nilai Variance Inflation Factor (VIF) juga menunjukkan hal yang sama, tidak ada satu variabel independen yang memiliki nilai VIF lebih dari 10. Jadi dapat disimpulkan bahwa tidak 


\section{Jurnal Akuntansi dan Pajak, 20(02), 2019, 140}

ada multikolonieritas antar variabel independen dalam model regresi.

3. Uji Heteroskedastisitas

Uji heterokedastisitas bertujuan menguji apakah dalam model regresi terjadi ketidaksamaan variance dari residual satu pengamatan ke pengamatan yang lain. Penelitian ini dalam menguji heterokedastisitas menggunakan grafik plot antara nilai prediksi variabel depnden yaitu ZPRED dengan residualnya SRESID. Tidak terjadi heteroskedastisitas apabila tidak ada pola yang jelas, serta titik-titik menyebar di atas dan di bawah angka 0 pada sumbu Y(Ghozali, 2018).

Berdasarkan gambar 1 terlihat bahwa titik-titik menyebar secara acak serta tersebar baik di atas maupun di bawah angka 0 pada sumbu Y. Hal ini dapat disimpulkan bahwa tidak terjadi heterokedastisitas pada model regresi, sehingga model regresi layak dipakai untuk memprediksi nilai perusahaan berdasarkan masukan variabel independen struktur modal, capital expenditure dan profitabilitas.

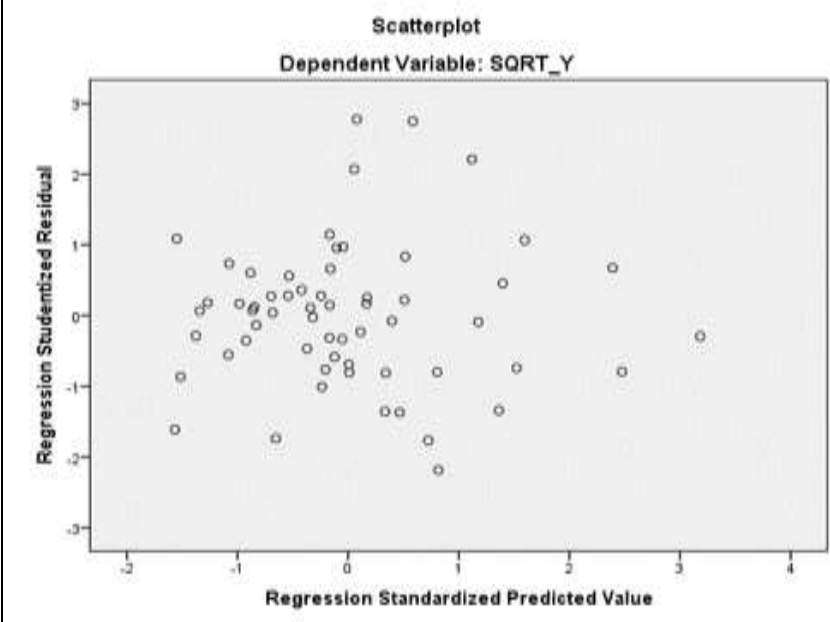

Gambar 1. Grafik Plot

4. Uji Autokorelasi

Uji autokorelasi bertujuan untuk menguji apakah dalam model regresi linear ada korelasi antara kesalahan pengganggu pada periode $\mathrm{t}$ 1(sebelumnya). Model regresi yang baik adalah regresi yang bebas dari autokorelasi. Penelitian ini menggunakan uji durbin Watson.

Tabel 3.

Model Summary ${ }^{\text {b }}$

\begin{tabular}{|l|c|r|r|r|r|}
\hline Model & $\mathrm{R}$ & $\begin{array}{c}\mathrm{R} \\
\text { Square }\end{array}$ & $\begin{array}{r}\text { Adjusted } \\
\text { R Square }\end{array}$ & $\begin{array}{l}\text { Std. Error of } \\
\text { the Estimate }\end{array}$ & $\begin{array}{r}\text { Durbin- } \\
\text { Watson }\end{array}$ \\
\hline 1 &, $523^{\mathrm{a}}$ &, 274 &, 221 &, 12738 & 1,960 \\
\hline
\end{tabular}

a. Predictors: (Constant), SQRT_X4,SQRT_X1,

SQRT_X2, SQRT_X3

b. Dependent Variable: SQRT_Y
Berdasarkan tabel 3., diperoleh DW 1,960 > du 1,7399 dan DW 1,960 < 4-du 2,2601. Berdasarkan hasil tersebut, sehingga dapat disimpulkan bahwa residual terjadi secara random atau tidak terjadi autokorelasi antar nilai residual.

\section{Uji Hipotesis}

Adapun uji hipotesis yang dilakukan meliputi uji koefisien determinasi, uji Signifikansi Simultan (Uji Statistik F) dan Uji Signifikansi Parameter Individual (Uji Statistik t).

a. Uji koefisien Determinasi

Koefisien determinasi $\left(\mathrm{R}^{2}\right)$ untuk mengukur seberapa jauh kemampuan model dalam menerangkan variasi variabel dependen.

Tabel 4.

Model Summary ${ }^{b}$

\begin{tabular}{|l|c|r|r|c|}
\hline Model & $\mathrm{R}$ & $\begin{array}{c}\mathrm{R} \\
\text { Square }\end{array}$ & $\begin{array}{c}\text { Adjusted } \\
\text { R Square }\end{array}$ & $\begin{array}{c}\text { Std. Error of the } \\
\text { Estimate }\end{array}$ \\
\hline 1 &, $523^{\mathrm{a}}$ &, 274 &, 221 &, 12738 \\
\hline
\end{tabular}

a. Predictors: (Constant), SQRT_X4, SQRT_X1, SQRT_X2,SQRT_X3

b. Dependent Variable: SQRT_Y

Berdasarkan tabel 4, dapat diketahui bahwa nilai $\mathrm{R}^{2}$ sebesar 0,274 . Hal ini berarti $27,4 \%$ variasi nilai perusahaan dapat dijelaskan oleh variasi dari keempat variabel struktur modal, capital expenditure, profitabilitas dan kebijakan dividen. Sedangkan sisanya $72,6 \%$ dijelaskan oleh sebabsebab yang lain di luar model.

b. Uji Signifikansi Simultan (Uji Statistik F)

Berdasarkan output spss, hasil uji $\mathrm{F}$ tersaji pada tabel 5.

Tabel 5.

ANOVA $^{\mathrm{a}}$

\begin{tabular}{|ll|r|r|r|r|r|}
\hline & Model & $\begin{array}{r}\text { Sum of } \\
\text { Squares }\end{array}$ & df & $\begin{array}{r}\text { Mean } \\
\text { Square }\end{array}$ & F & Sig. \\
\hline 1 Regression &, 337 & 4 &, 084 & 5,188 &, $001^{\mathrm{b}}$ \\
& Residual &, 892 & 55 &, 016 & & \\
& Total & 1,229 & 59 & & & \\
\hline
\end{tabular}

a. Dependent Variable: SQRT_Y

b. Predictors: (Constant), SQRT_X4, SQRT_X1, SQRT_X2,SQRT_X3

Berdasarkan uji ANOVA atau $F$ test didapat nilai $\mathrm{F}$ hitung sebesar 5,188 dengan probabilitas 0,001. Karena probabilitas jauh lebih kecil dari 0,05, maka model regresi dapat digunakan untuk memprediksi nilai perusahaan atau dapat dikatakan bahwa struktur modal, capital expenditure, profitabilitas dan kebijakan dividen secara bersamasama berpengaruh terhadap nilai perusahaan BUMN di Indonesia tahun 2015 - 2018. 


\section{Jurnal Akuntansi dan Pajak, 20(02), 2019, 141}

c. Uji Signifikansi Parameter Individual (Uji Statistik t)

Tabel 6.

Coefficients $^{\mathrm{a}}$

\begin{tabular}{|c|c|c|c|c|c|}
\hline \multirow[b]{2}{*}{ Model } & \multicolumn{2}{|c|}{$\begin{array}{c}\text { Unstandardized } \\
\text { Coefficients }\end{array}$} & \multirow{2}{*}{\begin{tabular}{|c|} 
Standardized \\
Coefficients \\
Beta \\
\end{tabular}} & \multirow[b]{2}{*}{$\mathrm{t}$} & \multirow[b]{2}{*}{ Sig. } \\
\hline & $\mathrm{B}$ & $\begin{array}{l}\text { Std. } \\
\text { Error }\end{array}$ & & & \\
\hline 1 (Constant) & ,910 &, 055 & & 16,684 & 000 \\
\hline SQRT_X1 & ,001 &, 025 & ,004 &, 028 & 977 \\
\hline SQRT_X2 & $4,839 \mathrm{E}-8$ &, 000 &, 336 & 2,565 & 013 \\
\hline SQRT_X3 &,- 344 &, 159 &,- 356 & $-2,161$ & ,035 \\
\hline SQRT_X4 & 320 &, 105 & ,461 & 3,061 & ,003 \\
\hline
\end{tabular}

a. Dependent Variable: SQRT_Y

Berdasarkan tabel 6, didapat koefisien regresi sehingga persamaan regresinya disusun sebagai berikut:

$$
\begin{gathered}
Y=a+\beta_{1} X_{1}+\beta_{2} X_{2}+\beta_{3} X_{3}+\beta_{4} X_{4}+e \ldots \ldots . . .(8) \\
Y=0,910+0,004 X_{1}+0,336 X_{2}+(-0,356) X_{3} \\
+0,461 X_{4}+e
\end{gathered}
$$

Penjelasan:

Konstanta (a)

a (alpha) pada persamaan diatas adalah nilai konstanta atau nilai tetap nilai perusahaan (Y) yang tidak dipengaruhi oleh struktur modal $\left(\mathrm{X}_{1}\right)$, capital expenditure $\left(\mathrm{X}_{2}\right)$, profitabilitas $\left(\mathrm{X}_{3}\right)$, dan kebijakan dividen $\left(\mathrm{X}_{4}\right)$ maka nilai perusahaan $(\mathrm{Y})$ bernilai sebesar nilai konstanta yaitu 0,910 .

Variabel Independen 1) $\beta 1=-0,004$.

Koefisien regresi untuk struktur modal $\left(\mathrm{X}_{1}\right)$ sebesar 0,004 artinya setiap penurunan/ berkurangnya satu satuan pada variabel struktur modal $\left(\mathrm{X}_{1}\right)$, akan menyebabkan perubahan/berkurangnya nilai perusahaan (Y) sebesar 0,004 poin, apabila variabel independen lain nilainya tetap.

$\beta 2=0,336$

Koefisien regresi untuk capital expenditure $\left(\mathrm{X}_{2}\right)$ sebesar 0,336, artinya setiap kenaikan/ bertambahnya satu satuan pada variabel capital expenditure $\left(\mathrm{X}_{2}\right), \quad$ akan menyebabkan perubahan/bertambahnya nilai perusahaan (Y) sebesar 0,336 poin, apabila variabel independen lain nilainya tetap.

$\beta 3=-0,356$

Koefisien regresi untuk profitabilitas $\left(\mathrm{X}_{3}\right)$ sebesar -0,356, artinya setiap penurunan/ berkurangnya satu satuan pada variabel profitabilitas $\left(\mathrm{X}_{3}\right)$, akan menyebabkan perubahan/berkurangnya nilai perusahaan $(\mathrm{Y})$ sebesar 0,356 poin, apabila variabel independen lain nilainya tetap.

$\beta 3=0,461$
Koefisien regresi untuk profitabilitas $\left(\mathrm{X}_{3}\right)$ sebesar 0,461 artinya setiap penurunan/ berkurangnya satu satuan pada variabel profitabilitas $\left(\mathrm{X}_{3}\right)$, akan menyebabkan perubahan/berkurangnya nilai perusahaan $(\mathrm{Y})$ sebesar 0,461 poin, apabila variabel independen lain nilainya tetap.

\subsection{Pembahasan}

Dari ke empat variabel independen yang dimasukkan kedalam model regresi, hanya variabel struktur modal yang diproksikan dengan DER yang tidak signifikan karena dapat dilihat dari probabilitas signifikansi untuk DER sebesar 0,977. Sedangkan variabel capital expenditure yang diproksikan dengan rasio CAPEX, profitabilitas yang diproksikan dengan net profit margin dan kebijakan dividen yang diproksikan dengan dividen payout ratio signifikan dengan probabilitas sebesar 0,013; 0,035 ; dan 0,003yang lebih kecil dari 0,05. Maka dapat disimpulkan bahwa variabel capital expenditure, profitabilitas dan kebijakan dividen berpengaruh signifikan terhadap nilai perusahaan yang diproksikan dengan rasio tobins $\mathrm{q}$.

Hipotesis struktur modal berpengaruh negatif terhadap nilai perusahaan dalam penelitian ini tidak diterima karena struktur modal tidak berpengaruh terhadap nilai perusahaan BUMN Indonesia pada tahun 2015 - 2018. Hasil penelitian ini tidak mendukung (Supit et al., 2015), (Hasibuan et al., 2016) dan (Situmeang and Wiagustini, 2018). Hasil ini menunjukkan bahwa investor tidak hanya berfokus pada jumlah hutang yang dimiliki perusahaan BUMN tapi pada faktor lain sehingga hasil penelitian ini tidak didukung oleh teori tradeoff.

Capital expenditure berpengaruh positif terhadap nilai perusahaan BUMN di Indonesia pada tahun 2015 - 2018. Hal ini menunjukkan bahwa capital expenditure perusahaan BUMN selama 2015 - 2018 dialokasikan pada penambahan, perbaikan atau peningkatan kualitas aktiva tetap yang menghasilkan manfaat jangka panjang. Hal ini menandakan adanya peluang-peluang investasi yang menarik minat para investor baru sehingga akan menghasilkan laba yang tinggi. Keputusan investasi yang diambil perusahaan BUMN tersebut akan memberikan sinyal positif pada pertumbuhan perusahaan di masa yang akan datang, sehingga meningkatkan harga saham dan nilai perusahaan akan meningkat. Penelitian ini mendukung (Rahmiati and Sari, 2013) dan (Andrian, 2012). 


\section{Jurnal Akuntansi dan Pajak, 20(02), 2019, 142}

Hipotesis profitabilitas berpengaruh positif terhadap nilai perusahaan dalam penelitian ini tidak diterima karena hasil penelitian ini menunjukkan profitabilitas berpengaruh negatif terhadap nilai perusahaan BUMN Indonesia pada tahun 2015 2018. Hal ini tidak sejalan dengan penelitian (Wahyu and Mahfud, 2018)dan (Gunawan, 2016). Profitabilitas dalam teori berhubungan positif dengan nilai perusahaan. Semakin tinggi profitabilitas maka nilai perusahaan tinggi dan semakin rendah profitabilitas maka nilai perusahaan rendah. Semakin baik perusahaan membayar return terhadap pemegang saham akan meningkatkan nilai perusahaan. Tetapi dalam penelitian ini berlawanan dengan teori karena profitabilitas yang diproksikan dengan net profit margin berpengaruh negatif. Hal ini menggambarkan bahwa semakin tinggi net profit margin yang dihasilkan maka akan menurunkan nilai perusahaan. Begitu juga sebaliknya semakin rendah net profit margin maka akan semakin tinggi nilai perusahaan. Berpengaruh negatif mengindikasikan bahwa net profit margin dipandang investor sebagai suatu keadaan perusahaan yang tidak menentu untuk BUMN di Indonesia periode 2015 - 2018 untuk masing-masing jenis usaha.

Kebijakan dividen berpengaruh positif terhadap nilai perusahaan BUMN Indonesia tahun 2015 2018 dalam penelitian ini diterima. Hal ini menunjukkan setiap kenaikan kebijakan dividen secara langsung dapat meningkatkan nilai perusahaan begitu juga sebaliknya apabila kebijakan dividen mengalami penurunan, maka nilai perusahaan secara otomatis mengalami penurunan. Besar kecilnya dividen yang dibayarkan oleh perusahaan BUMN akan sangat mempengaruhi pencapaian tujuan memaksimumkan kesejahteraan bagi pemegang saham.Hasil penelitian ini didukung theory bird in the hand, dimana pembagian dividen merupakan suatu pertanda bagi investor. Nilai ratarata kebijakan dividen dengan proksi DPR sebesar 0,4289 . Hal ini berarti rasio pembayaran dividen sebesar $42 \%$ dari laba yang akan dibagikan kepada pemegang saham. Hal ini menunjukkan bahwa perusahaan BUMN yang terdaftar di BEI periode 2015 - 2018 mengeluarkan 42\% laba yang dimiliki untuk dibagikan kepada pemegang saham sebagai dividen.Hasil penelitian ini mendukung penelitian (Rialdy, 2018) yang menyatakan bahwa kebijakan dividen berpengaruh positif dan signifikan terhadap Nilai Perusahaan pada perusahaan BUMN yang terdaftar diBursa Efek Indonesia tahun 2013-2017 dan juga mendukung (Rasyid, dan Yuliandhari, 2018) yang menyatakan kebijakan dividen berpengaruh positif terhadap nilai perusahaan BUMN.

Berdasarkan uji ANOVA didapat nilai $\mathrm{F}$ hitung sebesar 5,188 dengan probabilitas 0,001 sehingga struktur modal, capital expenditure, profitabilitas dan kebijakan dividen secara bersama-sama berpengaruh terhadap nilai perusahaan BUMN di Indonesia tahun 2015 - 2018.Nilai perusahaan sebesar $27,4 \%$ dapat dijelaskan oleh variasi dari keempat variabel struktur modal, capital expenditure, profitabilitas dan kebijakan dividen. Sedangkan sisanya $72,6 \%$ dijelaskan oleh sebabsebab yang lain di luar model.

\section{Kesimpulan}

Berdasarkan analisis yang dilakukan, maka dapat disimpulkan sebagai berikut:

a. Struktur modal yang diproksikan dengan debt to equity ratiotidak berpengaruh terhadap nilai perusahaan BUMN Indonesia pada tahun 2015 2018

b. Capital expenditure berpengaruh positif terhadap nilai perusahaan BUMN di Indonesia pada tahun $2015-2018$.

c. Profitabilitas berpengaruh negatif terhadap nilai perusahaan BUMN Indonesia pada tahun 2015 2018

d. Kebijakan dividen berpengaruh positif terhadap nilai perusahaan BUMN Indonesia tahun 2015 2018

e. Struktur modal, capital expenditure, profitabilitas dan kebijakan dividen secara bersama-sama berpengaruh terhadap nilai perusahaan BUMN di Indonesia tahun 2015 - 2018.

Berdasarkan kesimpulan tersebut, maka saran untuk penelitian ini yaitu perusahaan BUMN yang diteliti diklasifikasikan menurut jenisnya sehingga bisa lebih valid untuk jenis-jenis perusahaan BUMN yang ada di Indonesia.

\section{Daftar Pustaka}

Andrian, J., 2012. Pengaruh Struktur Modal , Pertumbuhan Perusahaan , Capital Expenditure Dan Insentif Manajer. J. Bisnsi Strateg. 21, 1849.

Anita, A., Yulianto, A., 2016. PENGARUH KEPEMILIKAN MANAJERIAL DAN KEBIJAKAN DIVIDEN TERHADAP NILAI PERUSAHAAN. J. Reprod. Infertil. 5, 17-23. 


\section{Jurnal Akuntansi dan Pajak, 20(02), 2019, 143}

Dewi, A.S.M., Wirajaya, A., 2013. Pengaruh Struktur Modal , Profitabilitas Dan. E-Jurnal Akunt. Univ. Udayana 2, 358-372.

Esana, R., Darmawan, A., 2017. Pengaruh Kebijakan Dividen Dan Keputusan Investasi Terhadap Nilai Perusahaan Serta Dampaknya Terhadap Profitabilitas. J. Adm. Bisnis 50, 110.

Ghozali, I., 2018. Aplikasi Analisis Multivariate Dengan Program IBM SPSS 25, 9th ed. Badan Penerbit -UNDIP, Semarang.

Gunawan, L., 2016. Pengaruh Net Profit Margin dan Total Asset Turnover Terhadap Nilai Perusahaan Pada Sektor Industri Barang Konsumsi Yang Terdaftar Di Bursa Eefek Indonesia. J. Ilm. Sekol. Tinggi Ilmu Ekon. Widya Dharma Pontianak 07, 22-31.

Hamidy, R.R., Wiksuana, I.G.B., Gede, L., Artini, S., 2015. Dengan Profitabilitas Sebagai Variabel Intervening Pada Perusahaan Properti Dan Real Estate Di Bursa Efek Indonesia. EJurnal Ekon. dan Bisnis Univ. Udayana 4, 665682.

Harjito, D.A., 2011. Teori Pecking Order dan TradeOff dalam Analisis Struktur Modal di Bursa Efek Indonesia. J. Siasat Bisnis 15, 187-196.

Hasibuan, V., Dzulkirom AR, M., Wi Endang NP, N., 2016. PENGARUH LEVERAGE DAN PROFITABILITAS TERHADAP NILAI PERUSAHAAN (Studi pada Perusahaan Property dan Real Estate yang Terdaftar di Bursa Efek Indonesia Periode Tahun 20122015). J. Adm. Bisnis S1 Univ. Brawijaya 39, 139-147.

Indasari, A.P., Yadnyana, I.K., 2018. Pengaruh Profitabilitas, Growth Opportunity, Likuiditas, dan Struktur Modal Pada Nilai Perusahaan. EJurnal Akunt. 22, 714.

Kurnia, D., 2017. Analisis Signifikansi Leverage Dan Kebijakan Deviden Terhadap Nilai Perusahaan. Anal. SIGNIFIKANSI LEVERAGE DAN Kebijak. DEVIDEN TERHADAP NILAI Perusah. Denny 4, 12-21.

Lestari, S., 2015. Determinan Struktur Modal Dalam Perspektif Pecking Order Theory dan Agency Theory ( Studi Empiris Pada Perusahaan Manufaktur yang Listing di BEI. J. WRA 3, 571-590.

Mutiara, N.A., Kartawinata, B.R., 2015. Pengaruh Capital Expenditure Terhadap Tingkat Laba ( Pada Perusahaan Jasa Telekomunikasi yang Terdaftar di Bursa Efek Indonesia Periode 2009-2013 ). J. Fak. Komun. dan Bisnis Univ. Telkom 1-9.
Rahmiati, Sari, W., 2013. Pengaruh Capital Expenditure, Struktur Modal Dan Profitabilitas Terhadap Nilai Perusahaan (Studi Pada Perusahaan Manufaktur Yang Terdaftar Di Bursa Efek Indonesia). J. Kaji. Manaj. Bisnis 2, $1-14$.

Rasyid, F.A., Yuliandhari, W.S., 2018. Pengaruh Biaya Corporate Social Responsibility dan Kebijakan Dividen Terhadap Nilai Perusahaan (Studi Pada Perusahaan BUMN yang terdaftar di Bursa Efek Indonesia 2012 - 2016). J. Akunt. Bisnis Ekon. IV.

Rialdy, N., 2018. Pengaruh Struktur Modal , Keputusan Investasi Dan Kebijakan Dividen Terhadap Nilai Perusahaan Pada Perusahaan BUMN Yang Terdaftar Di BEI Periode 2013 2017. Liabilities J. Pendidik. Akunt. 1, 272288.

Sarafina, S., Saifi, M., 2017. Pengaruh Good Corporate Governance Terhadap Kinerja Keuangan dan Nilai Perusahaan ( Studi pada Badan Usaha Milik Negara ( BUMN ) yang Terdaftar di Bursa Efek Indonesia Periode 2012-2015). J. Adm. Bisnis 50, 108-117.

Senata, M., 2016. Pengaruh Kebijakan Dividen Terhadap Nilai Perusahaan Yang Tercatat Pada Indeks Lq-45 Bursa Efek Indonesia. Jurbal Wira Ekon. Mikrosil 6, 73-84.

Situmeang, Y.M.L., Wiagustini, N.L.P., 2018. Pengaruh struktur modal terhadap nilai perusahaan dengan kebijakan herging sebagai mediasi pada perusahaan BUMN Go-Public. EJurnal Manaj. Unud 7, 1368-1396.

Sofiamira, N.A., Asandimitra, N., 2017. Capital Expenditure, Leverage, Good Corporate Governance, Corporate Social Responsibility: Pengaruhnya Terhadap Nilai Perusahaan. J. Ekon. dan Bisnis 20, 191.

Sudiyatno, B., Puspitasari, E., 2010. TOBIN'S Q dan ALTMAN Z-SCORE Sebagai Indikator Pengukuran Kinerja Perusahaan. Kaji. Akuntanasisi 2, 9-21.

Sudiyatno, B., Puspitasari, E., Kartika, A., 2012. The Company's Policy, Firm Performance, and Firm Value: An Empirical Research on Indonesia Stock Exchange. Am. Int. J. Contemp. Res. 2, 30-40.

Supit, H.V., Herman, K., Jenny, M., 2015. Pengaruh Struktur Modal, Biaya Ekuitas, dan Kebijakan Dividen Terhadap Nilai Perusahaan Pada Badan Usaha Milik Negara (BUMN) Yang Terdaftar Di Bursa Efek Indonesia. PhD Propos. 1, 1-18. 


\section{Jurnal Akuntansi dan Pajak, 20(02), 2019, 144}

Wahyu, D.D., Mahfud, M.K., 2018. ANALISIS PENGARUH NET PROFIT MARGIN , RETURN ON ASSETS , TOTAL ASSETS TURNOVER, EARNING PER SHARE, DAN DEBT TO EQUITY RATIO TERHADAP NILAI PERUSAHAAN ( Studi Pada: Perusahaan Manufaktur yang terdaftar di Bursa Efek Indonesia Periode 2010-2016 ). Diponegoro J. Manag. 7, 1-11.
Zurohtun, Yulianti, R., 2013. Kebijakan Dividen Pada Perusahaan Konservatif Dan Non Konservatif Serta Bumn Dan Non Bumn. J. Ilm. Akunt. dan Bisnis 8, 1-8. 